\title{
Ehretia microphylla Tablet Formulation for Biliary and Gastrointestinal Colic: A Review of its Phytochemical Constituents, Pharmacologic Activities and Clinical Researches
}

\author{
Charisse Leanne B. Legaspi and Daisy-Mae A. Bagaoisan \\ Institute of Herbal Medicine, National Institutes of Health, University of the Philippines Manila
}

\begin{abstract}
The persistence of human diseases challenges the current state of the discovery and production of synthetic drugs. Plants are recognized as a great resource to discover chemical compounds that can be used for drug development. In the Philippines, Ehretia microphylla (tsaang gubat) is recognized by the Department of Health as one of the ten recommended medicinal plants. This article aims to provide a comprehensive review of the traditional use, phytochemical constituents, pharmacologic activities as well as the non-clinical and clinical studies leading to the NIRPROMP formulation of the tsaang gubat tablet indicated for biliary and gastrointestinal pain. Among the phytochemical constituents observed were flavonoids, phenolics, triterpenes, and alkaloids. Evidence for other pharmacologic properties such as antibacterial, anti-angiogenesis, anti-oxidant, anti-inflammatory, anti-allergy, folliculogenesis, wound healing and anti-cancer activities are presented. Currently, tsaang gubat tablet has been granted a full patent for its invention as a tablet for relieving symptoms of biliary and gastrointestinal colic and is registered with the Philippine Food and Drug Administration for these indications. The tsaang gubat tablet is listed in the Philippine National Formulary after the conduct of in vitro, in vivo and Phase I-III clinical trials. Future platforms for research include the reformulation of the existing tsaang gubat drug for other indications, determination of the molecular mechanism of action and plans for plant conservation.
\end{abstract}

Key Words: Ehretia microphylla, tsaang gubat, gastrointestinal colic, biliary colic

\section{INTRODUCTION}

The emergence and re-emergence of infections, persistent environmental pollution, changes in lifestyles leading to human diseases and the costly synthetic drugs pose a challenge to the current state of the discovery of synthetic drugs. The field of ethnopharmacology focuses on the interdisciplinary scientific exploration of biologically active components that can be of use to man. ${ }^{1}$ There is currently a resurgence for the preference of natural products over synthetic ones.

In the Philippines, the Department of Health has recognized ten scientifically validated plants of medicinal value $^{2}$ including Vitex negundo (lagundi), Senna alata (akapulko), Momordica charantia (ampalaya), Allium sativum (bawang), Psidium guajava (bayabas), Quisqualis indica (niyog-niyogan), Blumea balsamifera (sambong), Ehretia microphylla (tsaang-gubat), Mentha $\times$ villosa (yerba buena) and Peperomia pellucida (ulasimang bato). In this paper, a review of the traditional use, phytochemical constituents, pharmacologic activities and the non-clinical and clinical 
studies leading to the formulation of the Philippine FDAapproved tsaang gubat tablet for diarrhea and abdominal pain are presented.

Tsaang gubat or the Philippine tea tree is an evergreen shrub native to India, Guandong and Hainan China, Ryuku Islands of Japan, Taiwan, Indonesia, Indochina, Malaysia, Papua New Guinea, Sri Lanka, Solomon Islands, and the Philippines. ${ }^{3,4,5}$ The shrub grows to up to 1.5-4.0 meters and has a highly branched, divaricate and brown bark, approximately $3 \mathrm{~mm}$ in thickness. ${ }^{5,6,7}$ The leaves are small, rounded and obovate and are around $1-25 \mathrm{~cm}$ in length and are $4-8 \mathrm{~mm}$ thickness with lobed apex and short bristly hairs. ${ }^{5,8,9}$ Its white flowers are axillary, solitary or present in two's on a slender and hairy peduncle ${ }^{1}$ while the orange to scarlet fruit has a globose shape and is a small drupe with a diameter of $4 \mathrm{~mm}$. It has a hard endocarp with one-celled pyrene. ${ }^{8,9}$ The roots are brown in color and are cylindershaped with approximately $10-40 \mathrm{~mm}$ diameter. ${ }^{7}$

\section{Taxonomic classification}

Kingdom: Plantae

Phylum: Tracheophyta

Class: Magnoliopsida

Order: Boraginales

Family: Boraginaceae

Genus: Ehretia

Specific epithet: Ehretia microphylla

Synonymous names: Carmona retusa (Vahl) Masam, Cordia retusa Vahl, Ehretia buxifolia Roxb. Ehretia heterophylla Spreng., Carmona heterophylla Cav., Carmona microphylla (Lam.) G. Don ${ }^{9,10}$

Common names: tsaang gubat, cha, chaang bundok, talibunog, icha, buyok-buyok, mara-mara, buyo-buyo, kalimong, alangitngit, Philippine tea tree; Fukien tree, chaa, chaa yeepun, serut lanang, scorpion brush, wild tea ${ }^{10}$

\section{Phytochemical constituents}

Phytochemical constituents can be classified as primary phytochemicals which include major biomolecules protein, carbohydrates and chlorophyll and the secondary phytochemicals consisting of alkaloids, saponins, tannins, and flavonoids. ${ }^{11,12}$ Table 1 summarizes the different phytochemicals observed in the different organs of tsaanggubat. It can be observed that flavonoids, alkaloids, phenols, and tannins were abundant in the plant even though different solvents and plant parts were used for the detection of these compounds.

Table 2 shows the specific secondary metabolites reported by various references from the different parts of tsaang gubat. The usual methods used for extraction were solvent partitioning and liquid chromatography. The three triterpenoids $\alpha$-amyrin, $\beta$-amyrin and bauerenol showed analgesic, antibacterial, antidiabetic, anti-diarrheal, antimutagenic, and anti-inflammatory activities. ${ }^{21}$ Also, the mixture of $\alpha$-amyrin and $\beta$-amyrin exhibited an anti- inflammatory response to acetic acid-,formalin- and capsaicininduced pain in mice. ${ }^{24}$ Microphyllone-related compounds such as dehydromicrophyllone, hydroxymicrophyllone, cyclomicrophyllone, allomicrophyllone were also observed ${ }^{25}$ while high-performance liquid chromatography (HPLC) analysis of dried leaves of the plant revealed the presence of rosmarinic acid. ${ }^{14}$

\section{Traditional uses of Tsaang gubat}

Tsaang gubat was used to treat diarrhea, spasm, inflammation, gastrointestinal and biliary colic in the Philippines. ${ }^{7}$ It is an important medicinal plant in the Indian system of traditional medicine. The leaves were widely used as relief for stomach ache, cough, fever, and constitutional syphilis. The roots were used by the people in Southern India to counter the effects of phytotoxins and syphilis. ${ }^{26}$ The leaves were used and prepared as a decoction to treat cough, stomach ache, diarrhea with bloody discharge and dysentery. ${ }^{27,28}$ The leaves were also used to improve fertility among women ${ }^{29}$ while the roots were known to have anti-venom ability. ${ }^{27,28}$

\section{Pharmacologic activities of tsaang gubat in non-clinical studies}

Reports on the plant's ability as an antibacterial, antioxidant, anti-inflammatory, antidiabetic, anti-allergenic, anticancer, fertility stimulator and in wound healing are summarized in Table 3.

At present, there are few reports on the molecular mechanism of action of tsaang gubat. Literature search produced one particular study which involved the use of a molecular docking strategy to determine the action of the plant extract. Results showed that among the fourteen bioactive compounds previously identified using GC$\mathrm{MS}^{27}$, 1-iod-2-methyl undecane and $2(1 \mathrm{H})$-naphthalenone, 3,5,6,7,8,8a-hexahydro-4,8a-dimethyl-6-(1-methylethenyl) binds strongly to the enzyme CYP17 (P450c 17 $\alpha) .{ }^{42}$ Women experiencing amenorrhea, sexual infantilism, hypertension, hypokalemia, and the polycystic ovarian syndrome were deficient in this protein. ${ }^{42,43}$ Specific amino acid residues such as Asp487, Ser488, Leu473, and Lys490 played important roles in binding with the ligands and on the receptor's activity.

\section{Tsaang gubat tablet (NIRPROMP formulation) as treatment for gastrointestinal and biliary colic}

Several studies were performed providing evidence for the safety and therapeutic efficacy of the plant.

\section{Pharmacologic and Toxicologic}

The mutagenicity and genotoxicity tests for the plant leaf alcoholic extract did not show chromosomefragmentation inducing activity. ${ }^{44}$ Further studies suggested the phytoene compound 4-hydroxy-7,8,11,12,15,7,8',11', $12^{\prime}, 15^{\prime}$-decahydro- $\beta$ - $\psi$-carotene prevented chromosomal 
Table 1. Phytochemical compounds detected in various parts of Ehretia microphylla

\begin{tabular}{|c|c|c|c|}
\hline Type of compound & Plant part & Solvent system & Reference \\
\hline \multirow{5}{*}{ Alkaloid } & aerial part & ethyl acetate, methanol & 6 \\
\hline & leaves & acetone, benzene & 6 \\
\hline & leaves & aqueous & 13 \\
\hline & leaves & ethanol & $13,14,15$ \\
\hline & leaves & methanol & 13,16 \\
\hline \multirow[t]{3}{*}{ Amino acids } & leaves & aqueous, benzene, petroleum ether & 15 \\
\hline & leaves & ethanol & 13,15 \\
\hline & leaves & methanol & 13 \\
\hline Anthraquinone & leaves & acetone, aqueous, benzene, ethanol, petroleum ether & 15 \\
\hline \multirow[t]{2}{*}{ Carbohydrates } & leaves & aqueous, benzene, ethanol & 15 \\
\hline & leaves & methanol & 17 \\
\hline Coumarin & leaves & benzene, petroleum ether & 15 \\
\hline Fixed oil & leaves & acetone, aqueous, benzene, ethanol, petroleum ether & 15 \\
\hline \multirow[t]{6}{*}{ Flavonoids } & aerial part & ethyl acetate, methanol & 8 \\
\hline & leaves & aqueous & 13,15 \\
\hline & leaves & benzene & 15 \\
\hline & leaves & chloroform, methanol & 13 \\
\hline & leaves & ethyl acetate & 15 \\
\hline & leaves & ethanol & $13,14,15$ \\
\hline Fluoride & leaf & infusion & 18 \\
\hline \multirow[t]{3}{*}{ Glycosides } & leaves & aqueous, ethanol & 13,15 \\
\hline & leaves & benzene & 15 \\
\hline & leaves & chloroform, ethyl acetate, methanol & 13 \\
\hline \multirow[t]{5}{*}{ Phenolic } & aerial part & ethyl acetate, methanol & 8 \\
\hline & leaves & acetone, benzene, petroleum ether & 15 \\
\hline & leaves & aqueous, chloroform, methanol & 13 \\
\hline & leaves & ethanol & 13,15 \\
\hline & leaves & ethyl acetate & 13,15 \\
\hline Polyphenols & fruit & methanol & 19 \\
\hline \multirow[t]{2}{*}{ Protein } & leaves & acetone, benzene & 15 \\
\hline & leaves & aqueous & 13,15 \\
\hline \multirow[t]{2}{*}{ Quinones } & aerial part & chloroform, ethyl acetate & 8 \\
\hline & leaves & acetone, aqueous, benzene, ethanol, petroleum ether & 15 \\
\hline \multirow[t]{4}{*}{ Saponin } & aerial part & methanol & 8 \\
\hline & leaves & acetone, aqueous, petroleum ether & 15 \\
\hline & leaves & chloroform, ethyl acetate, methanol & 13 \\
\hline & leaves & ethanol & 13,15 \\
\hline Starch & leaves & benzene, ethanol, petroleum ether & 15 \\
\hline \multirow[t]{4}{*}{ Steroid } & aerial part & hexane & 8 \\
\hline & leaves & benzene, petroleum ether & 15 \\
\hline & leaves & ethanol & 13,15 \\
\hline & leaves & methanol & 13 \\
\hline Sterol & leaves & methanol & 17 \\
\hline \multirow[t]{6}{*}{ Tannins } & aerial part & methanol & 8 \\
\hline & leaves & acetone, benzene, petroleum ether & 15 \\
\hline & leaves & aqueous & 13,15 \\
\hline & leaves & chloroform, ethyl acetate & 13 \\
\hline & leaves & methanol & 13,16 \\
\hline & leaves & ethanol & $13,14,15$ \\
\hline \multirow[t]{3}{*}{ Terpenoids } & leaves & acetone & 15 \\
\hline & leaves & aqueous & 13,15 \\
\hline & leaves & ethyl acetate, ethanol, methanol & 13 \\
\hline \multirow[t]{3}{*}{ Triterpene } & aerial part & chloroform, hexane, ethyl acetate & 8 \\
\hline & leaves & acetone, aqueous, ethanol, benzene, petroleum ether & 15 \\
\hline & leaves & methanol & 21 \\
\hline
\end{tabular}


Table 2. Specific secondary metabolites isolated from tsaang gubat

\begin{tabular}{|c|c|c|}
\hline Plant part & Solvent used for extraction & Specific metabolite \\
\hline \multirow[t]{2}{*}{ Leaves } & ethanol & Microphyllone $e^{20}$ \\
\hline & methanol & $\begin{array}{l}\text { Kaempferol-3-O-glucoside (sstragalin) }{ }^{14}, \text { kaempferol-3-O-rutinoside (nicotoflorin) }{ }^{14} \text {, } \\
\text { a-amyrin }{ }^{14,21,23}, \beta \text {-amyrin }{ }^{14,21,23}, \text { bauereno }\left.\right|^{14,21,23} \text {, rosmarinic acid }{ }^{14}\end{array}$ \\
\hline Aerial part & methanol & $\begin{array}{l}\text { Microphyllone-related compounds (dehydromicrophyllone, hydroxymicrophyllone, } \\
\text { cyclomicrophyllone, allomicrophyllone) }{ }^{25}\end{array}$ \\
\hline Root bark & methanol & Ehretianone, $\beta$-sitosterol, stigmasterol, $\alpha$-spinasterol, campesterol, cholesterol ${ }^{22}$ \\
\hline
\end{tabular}

Table 3. Summary of non-clinical studies on the biologic activities of tsaang gubat

Biological Activity Part Used - Solvent Used Results

Antimicrobial leaf - ethanol

- effective against methicillin-resistant Staphylococcus aureus strains (MRSA 1, 2, 3, 4), MBL Acinetobacter boumannii, Staphylococcus aureus, Pseudomonas aeruginosa, and Bacillus subtilis

- ineffective against Gram-negative bacteria such as Escherichia coli ${ }^{30}$

\begin{tabular}{ll} 
& $\begin{array}{l}\text { leaf - acetone } \\
\text { leaf - hexane } \\
\text { aqueous } \\
\text { root - chloroform, and } \\
\text { alcohol }\end{array}$ \\
\hline Anti-angiogenesis & leaf - ethanol \\
leaf - methanol \\
\hline $\begin{array}{l}\text { Anti-oxidant } \\
\text { froperty }\end{array}$ \\
\\
stem - ethyl acetate \\
stem - ethanol \\
leaf - aqueous
\end{tabular}

- active against $P$. aeruginosa ${ }^{30}$

- effective against S. aureus and B. subtilis ${ }^{31}$

- partial inhibition of E. coli and S. aureus ${ }^{32}$

- inhibited the growth of B. cereus, B. subtilis, E. coli, K. pneumonia, P. pride, S. aureus, S. typhimurium, and C. albicans growth but no observed activity towards E. aerogenes and $P$. aeruginosa $a^{7}$

- inhibition of blood vessel branching in ten-day-old fertilized eggs assessed using the Chick Chorioallantoic Membrane (CAM) assay, similar to the action of retinoic acid ${ }^{33}$

- decreased blood vessel branching comparable to quercetin by impeding the complex process of blood vessel formation (endothelial cell formation and proliferation and protein-protein interactions) inducing apoptosis ${ }^{17}$

- Ferric Reducing Antioxidant Power (FRAP) assay and 2,2-diphenyl-1-picrylhydrazyl (DPPH) radical scavenging assay revealed favorable antioxidant activity in suggesting that the high carotenoid and ascorbate content in the fruits had this activity

- high activity of antioxidant enzymes such as peroxidase, catalase, and superoxide dismutase ${ }^{19}$

- maximum DPPH, hydrogen peroxide scavenging, FRAP reducing, nitric oxide, iron chelating and superoxide scavenging activities ${ }^{34}$

- maximum DPPH and hydrogen peroxide scavenging, FRAP reducing, nitric oxide, iron chelating and superoxide scavenging activities ${ }^{35}$

- dose-dependent scavenging action against DPPH, ABTS and hydroxyl radicals, FRAP and nitric oxide assay similar to vitamin $C^{36}$

\begin{tabular}{|c|c|c|}
\hline \multirow[t]{3}{*}{ Anti-allergy } & leaf - methanol & - inhibited histamine release in mast cells with induced histamine production ${ }^{14}$ \\
\hline & stem - methanol & $\begin{array}{l}\text { - inhibited rat basophil destruction by limiting the release of hexosaminidase }{ }^{37} \\
\text { - microphyllone and prenylbenzoquinone had anti-allergic activity in RBL-2H3 cultures } \\
\text { incubated with DNP-specific IgE4 } 4^{25}\end{array}$ \\
\hline & leaf - decoction & $\begin{array}{l}\text { - improved symptoms for sneezing, rhinorrhea, nasal congestion and pruritus in patients } \\
\text { with mild intermittent allergic rhinitis }{ }^{38}\end{array}$ \\
\hline Anti-inflammatory & stem - ethanolic & $\begin{array}{l}\text { - anti-inflammatory and erythrocyte protective activity in RBC placed in hypotonic } \\
\text { solution by stabilizing the lysosomal membrane } \\
\text { - extracts prevented the heat-induced RBC hemolysis and proteinase released by } \\
\text { the leukocytes }{ }^{39,40}\end{array}$ \\
\hline Anti-cancer & stem - ethanolic & $\begin{array}{l}\text { - antimitotic activity - decreased mitotic index compared to the control; antiproliferation, } \\
\text { necrosis induction and genomic DNA fragmentation in S. cerevisiae samples }{ }^{39}\end{array}$ \\
\hline $\begin{array}{l}\text { Folliculogenesis } \\
\text { stimulant }\end{array}$ & & $\begin{array}{l}\text { - stimulated folliculogenesis among female Wistar mice by increasing the production } \\
\text { of luteinizing hormone, follicle-stimulating hormone and estradiol. } \\
\text { - formation of primordial follicles, matured Graafian follicles and corpus luteum } \\
\text { observed in the ovarian tissues, suggesting the possible effect of the extract in } \\
\text { stimulating the hypothalamus-pituitary-ovarian axis }{ }^{8}\end{array}$ \\
\hline Wound healing & root - ethanol & $\begin{array}{l}\text { - ointment exhibited wound healing activity comparable with the standard drug } \\
\text { nitrofurazone. Rate of wound closure, re-epithelization, collagen deposition and } \\
\text { tensile strength of the granulation tissues were enhanced }{ }^{41}\end{array}$ \\
\hline
\end{tabular}


aberrations induced by tetracycline. ${ }^{20}$ The formulated tsaang-gubat tablet from the NAST pilot plant did not cause DNA-damaging capacity and was non-mutagenic or genotoxic. Moreover, there was an observed decrease in mitomycin $\mathrm{C}$-, tetracycline- and dimethylnitrosamoneinduced micronucleation in polychromatic red blood cells. ${ }^{15}$

Phytochemical tests of Tsaang gubat leaves detected the presence of alkaloids and tannins. An intractable mixture of triterpenes, which is a major constituent of tsaang gubat leaves, exhibited $29 \%$ and $55 \%$ antidiarrheal activity at dosages of 100 and $250 \mathrm{mg} / \mathrm{kg}$ body weight of mouse. ${ }^{21}$ Pharmacologic screening of the plant leaf decoction showed that it initially increased the tone, frequency, and amplitude of the rat duodenum movement in vitro. ${ }^{45} \mathrm{~A}$ significant decrease in intestinal motility (96\%) was also demonstrated using the charcoal tracing studies in mice at a dose of $20 \mathrm{~g} / \mathrm{kg}\left(\mathrm{ED}_{50}\right) \cdot{ }^{46}$

\section{Clinical Studies}

The formulation of NIRPROMP was a tsaang gubat tablet with $10 \%$ leaf aqueous extract at $150 \mathrm{mg} / \mathrm{kg} / \mathrm{dose}$ every 24 hours. In Phase 1 clinical trial conducted at Pila and Victoria, Laguna, five (5) male patients diagnosed with acute colic secondary to loose bowel movement were given the formulation. The observed effect after administration included: (1) relief of intestinal spasms or colic in all patients; (2) decreased frequency of bowel movement by $70 \%$ and quantity of stool by $60-70 \%$ in 4 of 5 patients and (3) the onset of effect (relief of colic generally occurred 20-30 minutes post-dosing). ${ }^{47}$ In Phase II clinical trials at the Tarlac Provincial Hospital, the dose of $150 \mathrm{mg} / \mathrm{kg} / \mathrm{dose}$ of tsaang gubat tablet showed comparable efficacy, safety and acceptability similar to dicycloverine at $0.5 \mathrm{mg} / \mathrm{kg} /$ dose among 110 out-patients with acute mild, moderate or severe biliary colic. Total pain relief was achieved in $1 \frac{1 / 2}{2}$ hour. There were no adverse effects reported by the patients nor were there any abnormalities in the laboratory exams performed after intake of the tsaang gubat tablet. ${ }^{48}$

Antispasmodic effect of tsaang gubat tablet compared with dicycloverine among patients with mild, moderate or severe gastrointestinal/abdominal colic and biliary colic (pain due to biliary stone) was investigated for the Phase III clinical study. ${ }^{49}$ The oral administration of either tablet of tsaang gubat or dicycloverine in 200 adult patients showed comparable results. This was demonstrated over time based on statistical analysis on Total Pain Intensity Difference (PID), Sum Pain Intensity Difference (SPID) and Total Pain Relief Score (TOTPAR) from the verbal response of patients wherein the onset of pain relief was within 30 minutes and complete pain relief was seen in 1-2 hours. There were three patients in each of the treatment groups who reported nausea, however, no other adverse effects were reported.

These researches were submitted to the Intellectual Property Office and the tsaang gubat (NIRPROMP formulation) tablet was granted a full patent as an invention to treat biliary and gastrointestinal colic. It has been licensed to a few local pharmaceutical companies and has been registered with the Philippine Food and Drug Administration and is currently listed in the Philippine National Formulary.

\section{CONCLUSION}

Current literature on the phytochemical constituents and pharmacological activities of Ebretia microphylla, more commonly known as tsaang gubat, was presented. The results of the studies compiled in this review could serve as a lead for further investigation of tsaang-gubat's other medicinal uses. Currently, the tsaang gubat tablet (NIRPROMP formulation) has been proven to be safe and effective in the relief of pain from gastrointestinal and biliary colic as there were no adverse effects found among the patients who joined the clinical trial. If tsaang gubat is also found to be useful for other indications through non-clinical and clinical studies, specific formulations may need to be developed. This way, we can maximize the medicinal properties of the plant.

It is also important that the elucidation of the molecular mechanism of action of these plants must be performed. Knowing the bioactive compounds can help breeders, conservation biologists, and biotechnologists in creating a protocol on how to enhance the production of these compounds in a single plant without threatening the plant's diversity and availability.

\section{Statement of Authorship}

All authors participated in data collection and analysis, and approved the final version submitted.

\section{Author Disclosure}

All authors declared no conflict of interest. The NIRPROMP-IHM has a patent on the tsaang gubat tablet formulation.

\section{Funding Source}

This paper was funded by the authors.

\section{REFERENCES}

1. Ghorbani A, Naghibi F, Mosaddegh M. Ethnobotany, ethnopharmacology and drug discovery. Iran J Pharm Sci. 2006; 2(2):109-18.

2. Ammakiw CL, Odiem MP. Availability, preparation and uses of herbal plants in Kalinga, Philippines. Eur Sci J. 2013; 4:483-90.

3. Mageswari S, Karpagam S. Macro and microscopical evaluation of root of Carmona retusa (Vahl.) Masam. IJIPSR. 2015a; 3(5): 551-9.

4. Raterta R, de Guzman GQ, Alejandro GJD. Assessment, inventory and ethnobotanical survey of medicinal plants in Batan and Sabtang Island (Batanes Group of Islands, Philippines). Int J Pure App Biosci. 2014; 2(4):147-54.

5. Starr F, Starr K, Loope L. Carmona retusa. In: United States Geological Survey-Biological Resources Division, Haleakala Field Station, Maui, Hawaii. 2003; pp. 1-4. 
6. Aarthi V, Shakila R, Sasikala E, Pitchiakumar M. Pharmacolognostical studies on Ehretia microphylla Lamk. Asian J Tradit Med. 2014; 9(5):118-29.

7. Mageswari S, Karpagam S. Evaluation of antimicrobial studies on root of Carmona retusa (Vahl.) Masam. Int J Curr Pharm Res. 2015; 7(3):60-3.

8. Aarthi V, Anbu J, Nazeer Ahmed KFH, Anjana A, Velpandian V. Effect of Ehretia microphylla Lamk on stimulation of reproductive function and ovarian folliculogenesis in rats. Int J Pharm Bio Sci. 2012; 3(3):273-80

9. Lorence DH, Flynn TW, Wanger WL. Contributions to the flora of Hawai'i. III. Bishop Mus Occas Pap. 1995; 41:19-58

10. Maramba-Lazarte CC, Cortes-Maramba NP, Palacpac JB, Amor EC, Quintana EG, Quijano RF, et al. Guidebook on the proper use of medicinal plants. National Integrated Research Program on Medicinal Plants, Institute of Herbal Medicine, National Institute of Health, University of the Philippines Manila. 2017; pp 48-49, 52

11. Edeoga HO, Okwu DE, Mbaebie BO. Phytochemical constituents of some Nigerian medicinal plants. Afr J Biotechnol. 2005; 4(7):685-8.

12. Krishnaiah D, Devi T, Bono ASR, Sarbatly R. Studies on phytochemical constituents of six Malaysian medicinal plants. J Med Plants Res. 2009; 3(2):67-72.

13. Porter AG, Jänicke RU. Emerging roles of caspase-3 in apoptosis. Cell Death Differ. 1999; 6(2):99-104.

14. Rimando AM, Inoshiri S, Otsuka H, Kohda H, Yamasaki K, Padolina WG, et al. Screening for mast cell histamine release inhibitory activity of Philippine medicinal plants. Active constituents of Ehretia microphylla. The Japanese Journal of Pharmacognosy. 1987; 41(3):242-7.

15. Sylianco CYL, Blanco FRB, Lim CM. Mutagenicity, clastogenicity and antimutagenicity of medicinal plant tablets produced by the NSTA pilot plant IV. Tsaang gubat Tablets. Philipp J Sci. 1987; 116(3): 275-80.

16. Maeshima Y. Angiogenesis and cancer. In: Srivastava, R, ed. Apoptosis, Cell Signaling, and Human Diseases Molecular Mechanisms. Humana Press; 2007. pp. 35-61.

17. Camposano JE, Dela Torre GLT, Laxamana JG, Larcia II LLH. Screening for the anti-angiogenic activity of selected Philippine medicinal plants using chorioallantoic membrane assay. Mahidol Univ J Pharm Sci. 2016; 43(4):173-82.

18. Samaniego SA. Tsaang gubat as a potential fluoride mouthwash. Undergraduate thesis, UP Manila College of Dentistry. 1986.

19. Nayak J, Basak UC. Antioxidant potential of some lesser known wild edible fruits of Odisha. Eur J Exp Biol. 2015; 5(8):60-70.

20. Villaseñor IM, Edu DA. Antimutagen from leaves of Carmona retusa (Vahl.) Masam. Mutat Res. 1993; 298(3):215-8.

21. Villaseñor IM, Canlas AP, Faustino KM, Plana KG. Evaluation of the bioactivity of triterpene mixture isolated from Carmona retusa (Vahl.) Masam leaves. J Ethnopharmacol. 2004; 92(1):53-6.

22. Selvanayagam ZE, Gnanavendhan SG, Balakrishna K, Rao RB, Sivaraman J, Subramanian K, et al. Ehretianone, a novel quinonoid xanthene from Ehretia buxifolia with antisnake venom activity. J Nat Prod 1996; 59:664-7.

23. Villaseñor IM, Edu DA, Bremner JB. Triterpenoids of Carmona retusa (Vahl.) Masam. Philipp J Sci. 1992; 121(4):413-8.

24. Otuki MF, Ferreira J, Lima FV, Meyre-Silva C, Malheiros A, Muller LA, et al. Antinociceptive properties of mixture of $\alpha$-amyrin and $\beta$-amyrin triterpenes: Evidence for participation of protein kinase $\mathrm{C}$ and protein kinase A pathways. J Pharmacol Exp Ther. 2005; 313(1):310-8.

25. Yamamura S, Simpol LR, Ozawa K, Ohtani K, Otsuka H, Kasai R, et al. Antiallergic dimeric prenylbenzoquinones from Ehretia microphylla. Phytochemistry. 1995; 39(1):105-10.

26. De Padua L, Lugod G, Pancho J. Handbook on Philippine Medicinal Plants. In: Documentation and Information Section, Office of the Director of Research. UPLB: Philippines; 1982. pp. 1:21.

27. Amudha M, Rani S. GC-MS analysis of bioactive components of Cordia retusa (Boraginaceae). Hygeia J D Med. 2014; 6(1):12-9.
28. Shrisha DL, Raveesha KA, Nagabhushan. Bioprospecting of selected medicinal plants for antibacterial activity against some pathogenic bacteria. J Med Plants Res. 2011; 5(17):4087-93.

29. Ignacimuthu S, Ayyanar M, Sivaraman KS. Ethnobotanical investigations among tribes in Madurai District of Tamil Nadu (India). J Ethnobiol Ethnomed. 2006; 2:25.

30. Valle Jr. DL, Andrade JI, Puzon JJM, Cabrera EC, Rivera WL. Antibacterial activities of ethanol extracts of Philippine medicinal plants against multidrug-resistant bacteria. Asian Pac J Trop Biomed. 2015; 5(7):532-40.

31. Penecilla GL, Magno CP. Antibacterial activity of extracts of twelve common medicinal plants from the Philippines. J Med Plants Res. 2011; 5(16):3975-81.

32. Masilungan VA, Maranon J, Valencia VV. Some common Philippine medicinal plants containing antibacterial substances. Journal of the Philippine Pharmaceutical Association. 1955; 42(5):72-9.

33. Salas GM, Totaan EV. Selected Philippine herbal plant extracts as angiogenesis inhibitors using Chick Chorioallantoic Membrane (CAM) assay. Int Res J Biological Sci. 2015; 4(9):28-32.

34. Amudha M, Rani S. Evaluation of in vitro antioxidant potential of Cordia retusa. Indian J Pharm Sci. 2016; 78(1):80-6.

35. Chandrappa CP, Govindappa M, Anil Kumar NV, Channabasava R, Chandrasekar N, Umashankar T. Evaluation of in vitro antioxidant activity of ethanol extract of Carmona retusa (Vahl.) Masam. IJSER. 2013; 4(12):861-76.

36. Ramanathan R, Ramakrishnan M, Palani R, Kuppusamy S. Carmona retusa (Vahl.) Masamune-potential antioxidant natural medicine. Int J ChemTech Res. 2017; 10(6):565-74.

37. Dasgupta A. Beta-Hexosaminidase, Acetaldehyde-Protein Adducts, and Dolichol as Alcohol Biomarkers. In: Alcohol and its Biomarkers. Clinical Aspects and Laboratory Determination, USA: Elsevier Inc.; 2015. pp. 163-180.

38. Umali FAC, Chua AH. Ehretia microphylla (Tsaang gubat) versus Loratadine as treatment for allergic rhinitis: a randomized controlled trial. Philipp J Otolaryngol Head Neck Surg. 2017; 32(2):6-10.

39. Chandrappa CP, Govindappa M, Anil Kumar NV, Channabasava R. In vitro anti-inflammatory activity of Carmona retusa (Vahl.). World J Pharm Pharm Sci. 2013; 2(5):3991-7.

40. Fürst R, Zündorf I, Dingermann T. New knowledge about old drugs: the anti-inflammatory properties of cardiac glycosides. Planta Med. 2017; 83(12-13): 977-84.

41. Mageswari S, Karagam S, Aadinaath Reddy G. Evaluation of wound healing activity of the plant Carmona retusa (Vahl.) Masam., in mice. Int. J Int Sci Inn Tech. 2015; 4(5):1-4.

42. Amudha M, Rani S. Molecular docking on the phytoconstituents of Cordia retusa (Vahl) Masam for its anti-infertility activity. World J Pharm Sci. 2014; 2(12):1905-9.

43. Levran D, Ben-Shlomo I, Pariente C, Dor J, Maschiach S, Weissman A. Familial partial 17,20-desmolase and $17 \alpha$-hydroxylase deficiency presenting as infertility. J Assist Reprod Genet. 2003; 20(1):21-8.

44. Balboa JG, Lim-Sylianco CY. Antigenotoxic effects of drug preparations from lagundi, tsaang gubat and ulasimang bato. Philipp J Sci. 1993; 122(1):1-13.

45. Estrada HR, Pharmacological and Toxicological Studies of Philippine Medicinal Plants. Reports, PCHRD. 1980.

46. Quijano R. Bioassay of Indigenous Plant Products Used in Traditional Folk Medicine in the Philippines. PCHRD Technical Report, Bicutan, Taguig. 1986.

47. Maramba NC, et al. Commissioned research by the Philippine Council for Health Research and Development of the Department of Science and Technology-Philippines. 1980.

48. Maramba NC, et al. Commissioned research by the Philippine Council for Health Research and Development of the Department of Science and Technology-Philippines.1998.

49. Maramba NC, et al. Commissioned research by the Philippine Council for Health Research and Development of the Department of Science and Technology-Philippines. 2008. 